\title{
Konsentrasi Klorofil pada Beberapa Varietas Tanaman Puring (Codiaeum varigatum L.)
}

\author{
Yelni Gogahu a, Nio Song Ai a*, Parluhutan Siahaan a
}

aJurusan Biologi, FMIPA, Unsrat, Manado

\begin{tabular}{l}
\hline K A T A K U N C I \\
\hline konsentrasi klorofil \\
tanaman puring
\end{tabular}

\begin{abstract}
A B S TR A K
Tanaman puring memiliki varietas yang sangat banyak dan terdapat sekitar 260 varietas puring yang ada di Indonesia. Puring merupakan tanaman yang memiliki warna dan bentuk daun yang beragam seperti kuning, hijau, merah dan coklat sehingga tanaman puring dimanfaatkan sebagai tanaman hias warna-warni tersebut disebabkan karena adanya bermacam-macam pigmen warna didalam daun. Dalam proses fotosintesis klorofil atau pigmen hijau daun sangat diperlukan sehingga setiap daun sangat membutuhkan klorofil. Belum ada data yang menunjukkan apakah perbedaan dominansi warna pigmen daun juga mengandung perbedaan kandungan klorofilnya. Penelitian ini dilakukan untuk mengkaji pengaruh perbedaan warna daun pada 9 varietas dan perbedaan umur tanaman terhadap kandungan klorofil tanaman puring (puring cobra, puring spageti lokal, puring bor merah, puring jengkol, puring jempol, puring jet merah, puring kura-kura moncolor, puring bor cristata, puring lele) dan perbedaan umur daun tanaman terhadap kandungan klorofilnya. Hasil penelitian menunjukkan bahwa daun pada umur 3 bulan kandungan klorofilnya sama pada semua varietas baik kandungan konsentrasi klorofil total, klorofil a maupun klorofil b. Pada 3 varietas (puring cobra, puring spageti lokal dan puring bor merah) daun yang telah berumur 8 bulan mengandung konsentrasi klorofil total dan klorofil a yang berbeda antara daun muda dan daun tua sedangkan konsentrasi korofil b tidak berbeda pada semua varietas.
\end{abstract}

KE Y W OR D S

chlorophyll concentration croton plants

\begin{abstract}
A B S T R A C T
Croton plants has so many varieties. Around 260 varieties of Croton plants are found in Indonesia. Croton plant is a plant with various color leaves such as yellow, green, red and brown which make Croton plant is used to be a houseplant. Those colors exist because of many color pigment in leaf. Every leaf needs chlorophyll or green pigment in photosynthesis process. There is no data that shows different color leaves contain different amount of chlorophyll. This research is done in order to find out the effects of difference in color leaves and plants age towards chlorophyll contents in Croton plants (puring cobra, puring spageti lokal, puring bor merah, puring jengkol, puring jempol, puring jet merah, puring kura-kura moncolor, puring bor cristata, puring lele) and different leaves age towards chlorophyll contents. The results showed that the leaf at the age of 3 months has the same chlorophyll contents whether in total chlorophyll, a chlorophyll ad b chlorophyll with the other varieties. The leaf in the age of 8 months in 3 varieties (puring cobra, puring spageti lokal dan puring bor merah) contains different consentration of total chlorophyll and a chlorophyll between young leaves and older leaves while the concentration of $\mathrm{b}$ chlorophyll does not differ at all varieties.
\end{abstract}

TERSEDIA ONLINE

01 Agustus 2016

*Corresponding author: Jurusan Biologi FMIPA UNSRAT, Jl. Kampus Unsrat, Manado, Indonesia 95115; Email address: Nio_ai@yahoo.com 


\section{Pendahuluan}

Puring atau yang dikenal dengan croton (Codiaeum varigatum L.) adalah tanaman hias yang bernilai tinggi. Tanaman yang dulu lebih dikenal sebagai tanaman pendamping makam dan pagar, saat ini lebih dikenal sebagai tanaman hias yang menghiasi perumahan elit, kantor dan hotel. Bentuk dan warna daunnya yang khas dan berwarna-warni mampu memikat konsumennya untuk mengoleksi puring. Banyaknya varietas tanaman puring membuka peluang besar bagi masyarakat yang menyukai tanaman puring untuk dibudidayakan (Upadani et al., 2013).

Klorofil merupakan sebagian besar pigmen yang ditemukan dalam membran tilakoid kloroplas. Pigmen hijau pada daun berperan mengabsorpsi cahaya dalam fotosintesis fase I, yaitu reaksi fotolisis (Salisbury dan Ross, 1995). Pigmen klorofil tidak hanya berperan sebagai pigmen fotosintesis, tetapi juga bermanfaat sebagai obat kanker otak dan paruparu. Klorofil juga dapat digunakan sebagai desinfektan, antibiotik dan food supplement. Klorofil dapat digunakan sebagai food supplement (makanan tambahan) karena mengandung nutrisi yang dibutuhkan untuk tubuh manusia (Hendriani dan Setiari 2009). Klorofil juga merangsang pembentukan darah karena menyediakan bahan dasar dari pembentuk hemoglobin (Setiari dan Nurchayati 2009). Sumber klorofil di Indonesia sangat melimpah, tetapi pemanfaatan klorofil di Indonesia masih sangat minim (Abdilah et al., 2014).

Menurut Richardson et al. (2002) pigmen yang berperan penting dalam fotosintesis adalah pigmen yang dapat menyerap radiasi matahari dan yang dapat melepaskan elektron dalam proses fotokimia, sehingga mengubah energi cahaya menjadi energi kimia. Pigmen yang dimaksud adalah klorofil a dan klorofil b. Dengan demikian konsentrasi klorofil akan mempengaruhi berlangsungnya proses fotosintesis dalam tumbuhan. Warna hijau pada daun terjadi karena adanya pigmen pemberi warna hijau, yaitu klorofil. Warna hijau pada varietas tanaman puring sangat bervariasi dan luas area warna hijau pada masing-masing varietas juga tidak sama.

Menurut Sestak (1981) dalam Sumenda et al. (2011) bahwa kemampuan daun untuk berfotosintesis juga meningkat sampai daun berkembang penuh dan kemudian mulai menurun secara perlahan. Daun tua yang hampir mati, menjadi kuning dan tidak mampu berfotosintesis karena rusaknya klorofil dan hilangnya fungsi kloroplas.

\section{Material dan Metode}

Penelitian ini dilaksanakan pada bulan Maret 2015 sampai dengan Februari 2016. Penanaman puring dilaksanakan di rumah kaca yang berlokasi di Kelurahan Tingkulu, Wanea Manado, Sulawesi Utara. Ekstraksi klorofil daun dan analisis kandungan klorofil dilakukan di Laboratorium
Ekologi Jurusan Biologi FMIPA UNSRAT. Alat dan bahan yang digunakan botol kaca coklat $100 \mathrm{~mL}$, gelas ukur, mortar dan pestel, tissue, alat tulis, timbangan analitik, kertas label, saringan, gunting, kamera digital, spektofotometer tipe 3000 nanometer, botol air mineral $600 \mathrm{~mL}$ yang digunakan sebagai pot, zat pengatur tumbuh "growtone" media tanaman tanah yang berpasir, beberapa varietas puring (puring cobra, puring spageti lokal, puring bor merah, puring jengkol, puring jempol, puring jet merah, puring kura-kura moncolor, puring bor cristata, puring lele) dan alkohol 95\%.

Penelitian ini dilakukan dalam Rancangan Acak Lengkap (RAL) dengan 2 perlakuan dan 5 ulangan. Perlakuan pertama adalah varietas tanaman dan perlakuan kedua adalah umur daun tanaman. Tahap penelitian meliputi penanaman, pemeliharaan serta pengambilan sampel untuk diukur konsentrasi klorofil daunnya. Variabel pengamatan ialah konsentrasi klorofil total, klorofil a dan klorofil b berdasarkan varietas dan umur daun tanaman. Data dianalisis dengan analisis varian (ANAVA) dan dilanjutkan dengan uji BNT 5\% jika terdapat perbedaan konsentrasi klorofil.

\section{Hasil dan Pembahasan}

\subsection{Konsentrasi Klorofil Total pada Varietas- varietas Tanaman Puring}

Hasil analisis sidik ragam terhadap konsentrasi klorofil total pada 9 varietas tanaman puring (Tabel 1) menunjukkan bahwa konsentrasi klorofil total pada setiap varietas tanaman puring yang berumur 3 bulan bervariasi akan tetapi setelah dilakukkan uji ANAVA ternyata tidak terdapat perbedaan konsentrasi klorofil total yang ditunjukkan $\mathrm{F}$ hitung lebih kecil dari $\mathrm{F}$ tabel pada tingkat kepercayaan 95\%.

Tabel 1. Konsentrasi klorofil total (mg/L) pada varietas tanaman puring yang berumur 3 bulan.

\begin{tabular}{lc}
\hline \multicolumn{1}{c}{ Varietas } & Rata-rata \pm SD \\
\hline Puring jengkol & $26,91 \pm 15,43$ \\
Puring kura-kura & $22,43 \pm 14,74$ \\
monocolor & $12,61 \pm 4,14$ \\
Puring spageti lokal & $18,19 \pm 10,57$ \\
Puring jet merah & $11,00 \pm 3,95$ \\
Puring cobra & $27,73 \pm 10,92$ \\
Puring bor merah & $14,43 \pm 5,57$ \\
Puring lele & $26,59 \pm 16,18$ \\
Puring jempol & $33,48 \pm 20,38$ \\
\hline
\end{tabular}

Hasil analisis varian pada tingkat perbedaan umur daun tanaman puring yang berumur 8 bulan menunjukkan bahwa konsentrasi klorofil total yang 
dihasilkan pada daun tua dan daun muda berbeda nyata berdasarkan uji BNT 5\% (Tabel 2).

Tabel 2. Konsentrasi klorofil total (mg/L) berdasarkan umur daun tanaman (ratarata $\pm S D)$.

\begin{tabular}{lcc}
\hline \multicolumn{1}{c}{ Varietas } & Daun Tua & Daun muda \\
\hline Bor merah & $4,11 \pm 0,56$ a & $2,83 \pm 0,30 \mathrm{a}$ \\
Spageti lokal & $5,24 \pm 0,04 \mathrm{~b}$ & $3,22 \pm 0,14 \mathrm{a}$ \\
Cobra & $6,11 \pm 1,21 \mathrm{~b}$ & $3,59 \pm 0,14 \mathrm{a}$ \\
\hline
\end{tabular}

Keterangan: SD = standar deviasi; angka yang diikuti oleh huruf yang berbeda adalah berbeda nyata berdasarkan uji BNT 5\%

Pada varietas cobra konsentrasi klorofil total daun yang tua $(6,11 \pm 1,21 \mathrm{mg} / \mathrm{L})$ memiliki konsentrasi korofil yang lebih tinggi daripada konsentrasi klorofil total pada daun muda $(3,59 \pm$ $0,14 \mathrm{mg} / \mathrm{L})$ daun tua varietas spageti lokal $(5,24 \pm$ $0,04 \mathrm{mg} / \mathrm{L})$ memiliki konsentrasi klorofil total yang lebih tinggi daripada konsentrasi klorofil total pada daun muda $(3,22 \pm 0,14 \mathrm{mg} / \mathrm{L})$ dan pada varietas bor merah pada daun tua (4,11 $\pm 0,56 \mathrm{mg} / \mathrm{L})$ memiliki konsentrasi klorofil lebih tinggi daripada konsentrasi klorofil total pada daun muda $(2,83 \pm$ $0,30 \mathrm{mg} / \mathrm{L}$ ). Hal ini disebabkan oleh perbedaan metabolisme yang berkaitan dengan umur, morfologi dan faktor genetik daun pada tanaman (Biber 2007). Hasil penelitian ini tidak berbeda dengan penelitian Sumenda et al., (2010) yang melakukan penelitian kandungan klorofil pada tingkat perkembangan daun mangga yang berbeda. Daun hijau tua memiliki konsentrasi klorofil total yang lebih tinggi $(47,44 \mathrm{mg} / \mathrm{L})$ daripada daun hijau muda $(27,55 \mathrm{mg} / \mathrm{L})$.

\subsection{Konsentrasi Klorofil a pada Varietas-varietas Tanaman Puring}

Hasil analisis sidik ragam menunjukkan bahwa konsentrasi klorofil a pada varietas-varietas tanaman puring (Tabel 3) tidak berbeda yang ditunjukkan oleh $\mathrm{F}$ hitung yang lebih kecil dari $\mathrm{F}$ tabel $5 \%$.

Tabel 3. Konsentrasi klorofil a (mg/L) pada varietas tanaman puring yang berumur 3 bulan.

\begin{tabular}{ll}
\hline Varietas & Rata-rata \pm SD \\
\hline Puring jengkol & $15,65 \pm 7,33$ \\
Puring kura-kura monocolor & $12,10 \pm 5,39$ \\
Puring spageti lokal & $7,80 \pm 1,95$ \\
Puring jet merah & $10,97 \pm 4,80$ \\
Puring cobra & $6,79 \pm 2,75$ \\
Puring bor merah & $16,20 \pm 5,64$ \\
Puring lele & $10,07 \pm 4,65$ \\
Puring jempol & $15,65 \pm 8,21$ \\
Puring bor cristata & $19,09 \pm 9,97$ \\
\hline
\end{tabular}

Berdasarkan uji BNT 5\% konsentrasi klorofil a berbeda nyata antara umur daun tua dan daun muda (Tabel 4).

Tabel 4. Konsentrasi klorofil a $(\mathrm{mg} / \mathrm{L})$ berdasarkan umur daun tanaman puring berumur 8 bulan (rata-rata $\pm \mathrm{SD}$ )

\begin{tabular}{lll}
\hline Varietas & Daun Tua & Daun muda \\
\hline Bor merah & $2,77 \pm 0,50 \mathrm{a}$ & $1,57 \pm 0,08 \mathrm{a}$ \\
Spageti lokal & $3,65 \pm 0,58 \mathrm{~b}$ & $2,05 \pm 0,02 \mathrm{a}$ \\
Cobra & $3,99 \pm 0,64 \mathrm{~b}$ & $2,34 \pm 0,04 \mathrm{a}$ \\
\hline
\end{tabular}

Keterangan: SD = standar deviasi; angka yang diikuti oleh huruf yang berbeda adalah berbeda nyata berdasarkan uji BNT 5\%

Berdasarkan morfologi daun tanaman puring varietas cobra (Gambar 1) memiliki morfologi daun lebar (ovalis) dan mempunyai warna daun yang dominan hijau.

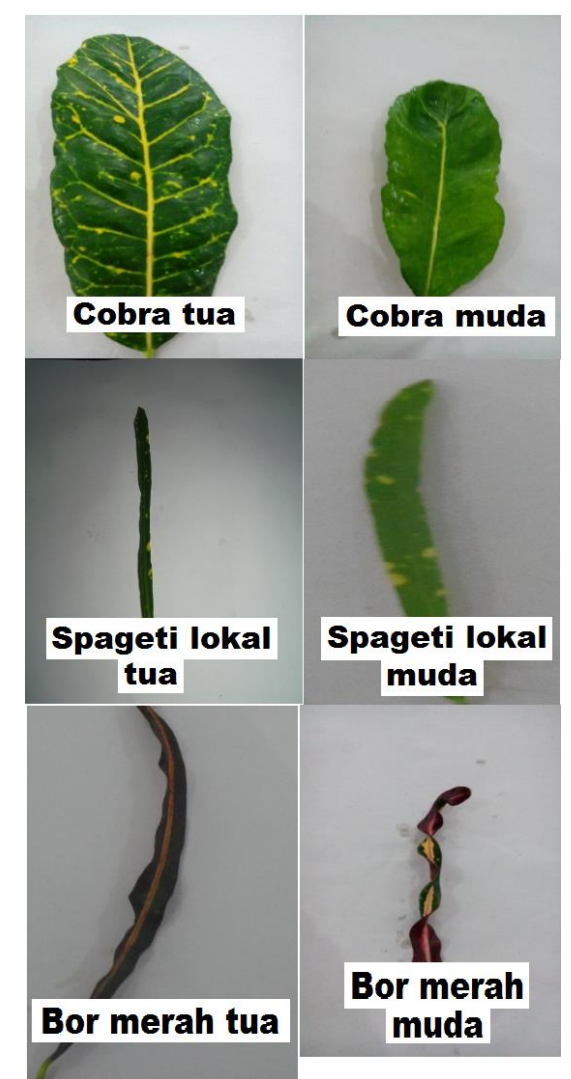

Gambar 1. Daun tua dan muda yang diekstraksi

Morfologi ini berbeda dengan morfologi daun pada spageti lokal dan bor merah yang sama-sama memiliki morfologi daun yang memanjang (lanceolatus). Varietas pada spageti lokal warna daun yang dominan adalah hijau kekuningan dan varietas bor merah memiliki warna daun yang dominan merah kecoklatan. Perbedaan morfologi dan warna daun ini menyebabkan puring varietas cobra memiliki konsentrasi klorofil a yang lebih tinggi $(3,16 \mathrm{mg} / \mathrm{L})$ daripada varietas spageti lokal $(2,84 \mathrm{mg} / \mathrm{L})$ dan bor merah $(2,16 \mathrm{mg} / \mathrm{L})$. 
Hasil penelitian Setiari dan Nurchayati (2009) menunjukkan bahwa konsentrasi klorofil a pada daun pepaya $(29,59 \mathrm{mg} / \mathrm{L})$ lebih tinggi daripada konsentrasi klorofil a pada daun kemangi $(13,82$ $\mathrm{mg} / \mathrm{L}$ ) hal ini dapat disebabkan karena daun pepaya merupakan tumbuhan yang sudah berumur lebih dari 3 bulan dan memiliki ukuran daun yang lebar, tetapi daun kemangi merupakan daun semusim dan hanya memiliki daun yang berukuran kecil dengan helaian daun yang tipis. Demikian pula kandungan klorofil pada tanaman daun sayuran pepaya $(29,59$ $\mathrm{mg} / \mathrm{L})$ dan singkong $(27,44 \mathrm{mg} / \mathrm{L})$ yang berumur di atas 3 bulan memiliki konsentrasi klorofil yang lebih tinggi daripada konsentrasi klorofil yang dihasilkan pada tanaman daun sayuran bayam $(23,03 \mathrm{mg} / \mathrm{L})$ dan kangkung $(16,76 \mathrm{mg} / \mathrm{L})$ yang berumur di bawah 3 bulan.

\subsection{Konsentrasi Klorofil b pada Varietas-varietas Tanaman Puring}

Hasil analisis sidik ragam untuk varietasvarietas tanaman puring (Tabel 5) menunjukkan bahwa konsentrasi klorofil $\mathrm{b}$ pada varietas-varietas tanaman puring tidak berbeda yang di tunjukkan oleh $\mathrm{F}$ hitung lebih kecil daripada $\mathrm{F}$ tabel $5 \%$ sehingga tidak dilanjutkan dengan uji BNT 5\%.

Tabel 5 Konsentrasi klorofil b $(\mathrm{mg} / \mathrm{L})$ pada varietas tanaman puring.

\begin{tabular}{ll}
\hline Varietas & Rata-rata \pm SD \\
\hline Puring jengkol & $11,29 \pm 9,09$ \\
Puring kura-kura monocolor & $10,35 \pm 9,74$ \\
Puring spageti lokal & $4,83 \pm 2,43$ \\
Puring jet merah & $7,24 \pm 5,96$ \\
Puring cobra & $4,23 \pm 1,81$ \\
Puring bor merah & $11,56 \pm 6,54$ \\
Puring lele & $4,37 \pm 0,98$ \\
Puring jempol & $10,97 \pm 8,56$ \\
Puring bor cristata & $14,43 \pm 11,63$ \\
\hline
\end{tabular}

Walaupun morfologi dan warna daun kesembilan varietas puring yang diamati bervariasi, tetapi konsentrasi klorofil b tidak berbeda diantara varietas dan pada daun muda dan daun tua. Perbedaan warna tersebut dapat disebabkan oleh konsentrasi pigmen lain selain klorofil (klorofil total, klorofil a, klorofil b) yang terkandung dalam daun varietas Codiaeum varigatum. Pigmen lain yang dimaksud ialah karoten, phalophytin dan xantofil (Ogunwenmo et al., 2007). Selanjutnya perbedaan variasi warna daun puring juga berkaitan dengan asilasi antosianin, kepigmentasi dengan flafanoid lain dan pembentukan kompleks dengan non logam (Papa et al., 2007).

Hasil analisis sidik ragam (Tabel 6) menunjukkan bahwa konsentrasi klorofil b tidak berbeda pada umur daun tua dan umur daun muda yang ditunjukkan oleh $\mathrm{F}$ hitung lebih kecil dari $\mathrm{F}$ tabel 5\%.

Tabel 6. Konsentrasi klorofil $\mathrm{b} \mathrm{mg} / \mathrm{L}$ berdasarkan umur daun tanaman (rata-rata $\pm \mathrm{SD}$ )

\begin{tabular}{lll}
\hline Varietas & Daun Tua & Daun muda \\
\hline Sapgeti lokal & $2,39 \pm 0,47$ & $1,47 \pm 0,18$ \\
Cobra & $4,97 \pm 0,31$ & $1,22 \pm 0,25$ \\
Bor merah & $5,6 \pm 0,21$ & $1,19 \pm 0,27$ \\
\hline
\end{tabular}

Perbedaan warna daun dapat disebabkan oleh variasi pigmen selain klorofil seperti antosianin, karoten atau yang lain. Hasil penelitian serupa juga diperoleh oleh Srichaikul et al., (2011) yang meneliti kandungan klorofil tumbuhan murbei (Morus alba) pada varietas/strain nekhorn ratchasrima-60 dan varietas strain burirum-60. Kandungan klorofil kedua varietas tersebut tidak berbeda.

\section{Kesimpulan}

Konsentrasi klorofil total, klorofil a dan klorofil b pada daun kesembilan varietas (puring cobra, puring spageti lokal, puring bor merah, puring jengkol, puring jempol, puring jet merah, puring kura-kura moncolor, puring bor cristata, puring lele) yang berumur 3 bulan tidak berbeda. Konsentrasi korofil total dan klorofil a pada daun ketiga varietas (puring cobra, puring spageti lokal dan puring bor merah) yang berumur 8 bulan berbeda antara daun muda dan tua, sedangkan konsentrasi korofil b tidak berbeda.

\section{Daftar Pustaka}

Abdilah F,. Raya. I. dan Ahmad. A. 2014. Pegujian Daya Antioksidan dan Sifat Toksisitas Ekstrak Co(II) Turunan Klorofil [Artikel ilmiah]. Jurusan Kimia FMIPA Universitas Hasanuddin. Makasar.

Biber, P.D. 2007. Evaluating a chlorophyll Content Meter on There Coastal Wetland Plant Species. Journal of Agricultural, Food and Environmental Sciences. 1(2): 1-11.

Hendriyani, I. S. dan Setiari, N. 2009. Kandungan Klorofil dan Pertumbuhan Kacang Panjang (Vigna sinensis) pada Tingkat Penyediaan Air yang Berbeda [Artikel Penelitian]. Jurusan Biologi FMIPA Universitas

Diponegoro. Semarang

Ogunwenmo, K. O., Idowu, O. A., Innocent, C., Esan, E. B. dan Oyelana, O. A. 2007. Cultivars Of (Codiaeum varigatum L.) Blume (Euphorbiacae) Show Variabelity In Phytochemical and Chytological Chalateristics. African Journal of Biotechnology. 6 (20): 2400-2405.

Papa, F. M., Avajiannli, B. dan Michos, C. 2007. Coloration Anthocyanin Contration and Growth of Croton (Codiaeum varigatum L.) as Affected by Cotton Gin Trash Compost Use in the Potting Medium. Hort Science 42 (1) $83-87$ 
Richardson, A. D., Dugan, S. P. dan Berlyn, G. P. 2002. An Evaluation of Noninvasive Mehtods to Estimate Foliar Chlorophyll Content. USA. Jurnal Phytologist 153 (1) : 185194

Salisbury, F. B. dan Ross, C. W. 1995. Fisiologi Tumbuhan. Jilid 2. Terj. : Lukman, D. R. dan Sumaryono. Penerbit ITB, Bandung.

Setiari, N. dan Nurchayati, Y. 2009. Ekplorasi Kandungan Klorofil pada Beberapa Sayuran Hijau sebagai Alternatif Bahan Dasar Food Suplement. Jurnal Bioma 11 (1) : 6-10

Srichaikul, B., Bunsang, R., Samappito, S., Butkhup, L. dan Bakker, G. $2011 . \quad$ Comparative
Study Chlorophyll Content in Leaves of Thai Morus alba Linn. Species. Plant Sciences Research. 3 (2): 17-20

Sumenda, L., Rampe, H. L. dan Mantiri, F. R. 2011. Analisis Kandungan Klorofil Daun Mangga (Mangifera indica L.) pada Tingkat Perkembangan Daun yang Berbeda. Jurusan Biologi Universitas Sam Ratulangi Manado.Jurnal Bioslogos 1(1) : 21-24

Upadani, W., Darmawan, D. P. dan Tenaya, I. N. 2013. Strategi Pengembangan Agribisnis Puring di Desa Petiga, Kecamatan Marga Kabupaten Tabanan. Jurnal Manajemen Agribisnis 1 (2): 67- 74 